\title{
Ethno-Medicinal Plants Used for Medication of Jaundice by The Chinese, Dayak, and Malays Ethnic in West Kalimantan, Indonesia
}

\author{
Ruqiah Ganda Putri Panjaitan ${ }^{1, *}$, Titin ${ }^{1}$, Yohanes Gatot Sutapa Yuliana²
}

\section{Ruqiah Ganda Putri Panjaitan ${ }^{1, *}$ Titin', Yohanes Gatot Sutapa Yuliana $^{2}$ \\ 'Biology Education Department, Faculty of Teacher Training and Education, Tanjungpura University, INDONESIA. ${ }^{2}$ English Education Department, Faculty of Teacher Training and Education, Tanjungpura University, INDONESIA. \\ Correspondence \\ Ruqiah Ganda Putri Panjaitan \\ Biology Education Department, Faculty of Teacher Training and Education, \\ Tanjungpura University, INDONESIA \\ E-mail: ruqiah.gpp@fkip.untan.ac.id \\ History \\ - Submission Date: 24-01-2021; \\ - Review completed: 03-03-2021; \\ - Accepted Date: 05-04-2021.}

DOI : 10.5530/pj.2021.13.118

Article Available online http://www.phcogj.com/v13/i4

Copyright

(c) 2021 Phcogj.Com. This is an openaccess article distributed under the terms of the Creative Commons Attribution 4.0 International license.

\begin{abstract}
Knowledge in the utilization of plants as medicine is local wisdom passed down from generation to generation. This study aims to make an inventory of plants that is efficacious in overcoming jaundice which is used by ethnic Chinese, Dayak, and Malay people in West Kalimantan. This research applies ethnobotany and medical ethnobiology approaches by using observation techniques, semi-structural interviews, also recording and documenting plant species to overcome jaundice. There were 23 types of medicinal plants used by ethnic Chinese, Dayak, and Malay people to overcome jaundice. The 23 types of plants obtained were tebu hitam (Saccharum officinarum L.), pisang mas (Musa paradisiaca L.), kacang hijau (Vigna radiata L.), bawang dayak (Eleutherine palmifolia (L.) Merr.), temulawak (Curcuma xanthorrhiza Roxb.), lipan-lipan (Chrysopogon aciculatus (Retz.) Trin), ciplukan (Physalis angulata L.), cha chen choul sawi (Plantago mayor L.), inai (Lawsonia inermis L), kunyit (Curcuma domestica Val.), kelapa gading (Cocos eburen Durch), belimbing manis (Averrhoa Carambola L.), ilalang (Imperata cylindrica (L) Beauv.), sia li chi o kin/putri malu kuning (Neptunia oleracea Lour.), ketepeng (Senna alata (L.) Roxb.), putri malu bunga ungu (Mimosa pudica L.), stet ma thio kin/bunga kancing (Urena lobata L.), tebu karak (Saccharum officinarum L.), kumis kucing (Orthosiphon aristatus (Blume) Miq.), empedu tanah/sambiloto (Andrographis paniculata (Burm.f.) Wall. Ex Nees), pegage/pegagan (Centella asiatica L. Urban), kai kut chou/tulang ayam (Clinacanthus nutans (Burm.f.) Lindau), and bambu kuning (Bambusa vulgaris Schrad.).
\end{abstract}

Key words: Jaundice, Local Wisdom, Medicinal plants.

\section{INTRODUCTION}

The liver is a vital organ located in the anterior abdomen. The liver has an important role in secreting bile salts, storing glycogen, synthesizing phospholipids, and detoxifying. ${ }^{1-6}$ As an organ that plays a role in detoxification, the liver often comes into contact with various substances or compounds that can damage the liver, that is why the liver needs to be protected to avoid damage so that it can carry out its function properly. Treating liver damage is less effective if it is done by consuming synthetic drugs, it may even cause side effects if used in the long term, besides the use of synthetic drugs is expensive. $^{?}$

In general, there are four markers of liver disease, which are seen from the general description of a damaged liver, the effect of liver disease on bile formation, impaired liver function, and the occurrence of liver cirrhosis. Furthermore, it is stated that a disturbance in the formation of bile can cause retention of the bilirubin pigment which results in the appearance of yellow color on the skin and eyeballs known as jaundice. ${ }^{8,9}$ A hepatoprotector is a substance that functions to protect the liver from damage while restoring damage to the liver. ${ }^{1-6,10}$ Previous research results showed that various plants that have the property to maintain liver function, including Hibiscus sabdariffa $a^{11}$, Eurycoma longifolia Jack. ${ }^{1}$, and Pithecellobium lobatum Benth. ${ }^{3}$
The availability of various types of plants provides various benefits for humans, one of which is as a medicinal ingredient. Indonesia has a very high biodiversity, so it is dubbed mega biodiversity. The available biodiversity is utilized to meet the needs of the community, especially for food and medicine. The use of plants as medicine has been carried out by people in Indonesia since ancient times, where this knowledge has been obtained from generation to generation. Usually, people make use of the plants that grow around their homes. ${ }^{12}$ There are many benefits of plants in medicine, including as an appetite enhancer ${ }^{12}$, improving body fitness ${ }^{13}$, hepatoprotector ${ }^{1,3}$, and antidiabetic mellitus. ${ }^{14}$

As in Indonesia ${ }^{12}$, many other countries in the world also use plants in medicine, including Malaysia ${ }^{15-17}$, the Philippines ${ }^{18,19}$, Thailand, China ${ }^{20}$, Korea ${ }^{21}, \operatorname{Iran}^{4}$, and India. ${ }^{2,5,22}$ Overall, it is stated that medicinal plants generally have lower side effects when compared to synthetic drugs. ${ }^{7,23,24}$

West Kalimantan is one of the provinces in Indonesia, which is located on Kalimantan Island. The area of West Kalimantan, which is mostly low lying land, is around 146,807 km2. West Kalimantan consists of 12 districts namely Kubu Raya, Kayong Utara, Ketapang, Mempawah, Landak, Sanggau, Sekadau, Sintang, Melawi, Kapuas Hulu, Bengkayang, and Sambas, as well as two cities namely Pontianak City and Singkawang City. The West Kalimantan region is inhabited by various ethnicities, based on data from the West Kalimantan Central Statistics Agency, the 
ethnic groups that dominate West Kalimantan are Dayaks, Malays, and Chinese. Each of these ethnic communities has local wisdom in utilizing plants obtained from hereditary heritage. The use of plants is not only needed to meet food needs but is also needed in various traditional ceremonies, as a food ingredient, and in medicine. This is what underlies the purpose of this research, namely to make an inventory of various types of plants that are efficacious to protect the liver, especially in overcoming jaundice which is used by the ethnic Chinese, Dayak, and Malay people in West Kalimantan.

\section{MATERIALS AND METHODS}

\section{Research sites}

The research location was chosen randomly from 14 districts/cities in West Kalimantan. Five districts/cities that were selected as research locations are Singkawang City, Bengkayang Regency, Sambas Regency, Sanggau Regency, and Sekadau Regency. The five districts/cities that were selected have the distribution of domicile of ethnic Chinese, Dayak, and Malay people. The research location points are presented in Figure 1.

\section{Research procedure}

The method in this study is a qualitative analysis method using the ethnobotany approach and medical ethnobiology, namely the study of traditional medicinal plants used by the community. ${ }^{25}$ Data collection techniques by applying observation techniques, semistructural interviews, also recording and documentation plant species to overcome jaundice. For sampling using a purposive sampling technique. The sample referred to is informants from ethnic Chinese, Dayak, and Malay who understand traditional medicinal plants and have experience in using plants as medicine. Thirteen informants were selected and they played a role in traditional medicine.

\section{RESULTS AND DISCUSSION}

Jaundice is a disease related to the liver. One of the marker aspects of liver disease is the disruption of bile formation which results in retention of the bilirubin pigment resulting in hyperbilirubinemia with symptoms of jaundice. ${ }^{8,9}$ Based on the results of this study, 23 types of plants were used to treat jaundice. Of the 23 types, plant organs used include roots, stems, leaves, seeds, a flesh of Cocos, and tubers. However, the most commonly used plant organs are the roots (Table 1.). Furthermore, it is known that plants have the power to overcome jaundice, which is the local wisdom of the community in five districts/ cities in this study which usually grows wild in the forest, but some have been cultivated in the yard, garden, or special land for medicinal plants. Regarding the knowledge about plants that can overcome jaundice, all informants said that the knowledge about the various types of plants and how to cultivate them was obtained from their ancestors and passed down from generation to generation. Besides, from the literature study, it is also known that the various types of plants used by the community have other properties, more than that, the potential and content of their chemical compounds have also been laboratory tested.

From this research, two varieties of sugarcane (Saccharum officinarum L.) were obtained, namely tebu hitam and tebu karak. Several previous researchers reported that Saccharum officinarum L. has medicinal properties including antibacterial ${ }^{26}$ and anti-cancer. ${ }^{27}$ Phytochemical test results show that Saccharum officinarum L contains alkaloid compound $s^{28}$, tannins ${ }^{26,28}$, saponins ${ }^{26}$, flavonoids ${ }^{26}$, also reducing sugars and anthracene glycosides ${ }^{26}$, carbohydrates ${ }^{26,28}$, protein $^{28}$, and resin. ${ }^{28}$

Studies that have been carried out on the Musa paradisiaca L plant, among others, show that banana flowers are reported to have anticancer properties ${ }^{29}$ and banana leaves can be used to treat wounds. ${ }^{30}$ The various research results summarized show that this plant has been shown to have acted as a hepatoprotector, diuretic, analgesic, antiulcer, wound healing, antioxidant, allergy, antibacterial, antihypertensive, and hypoglycemic. ${ }^{31}$ Moreover, banana peels are reported to contain alkaloid compounds, flavonoids, saponins, polyphenols, quinones, steroids, quinones, and triterpenoids. ${ }^{32}$

Vigna radiata $\mathrm{L}$. is reported to have potential as antibacterial ${ }^{33}$ and antioxidants. ${ }^{33,34}$ The results of phytochemical testing showed that Vigna radiata L. seed extract contains flavonoid compounds ${ }^{33,34}$, as well

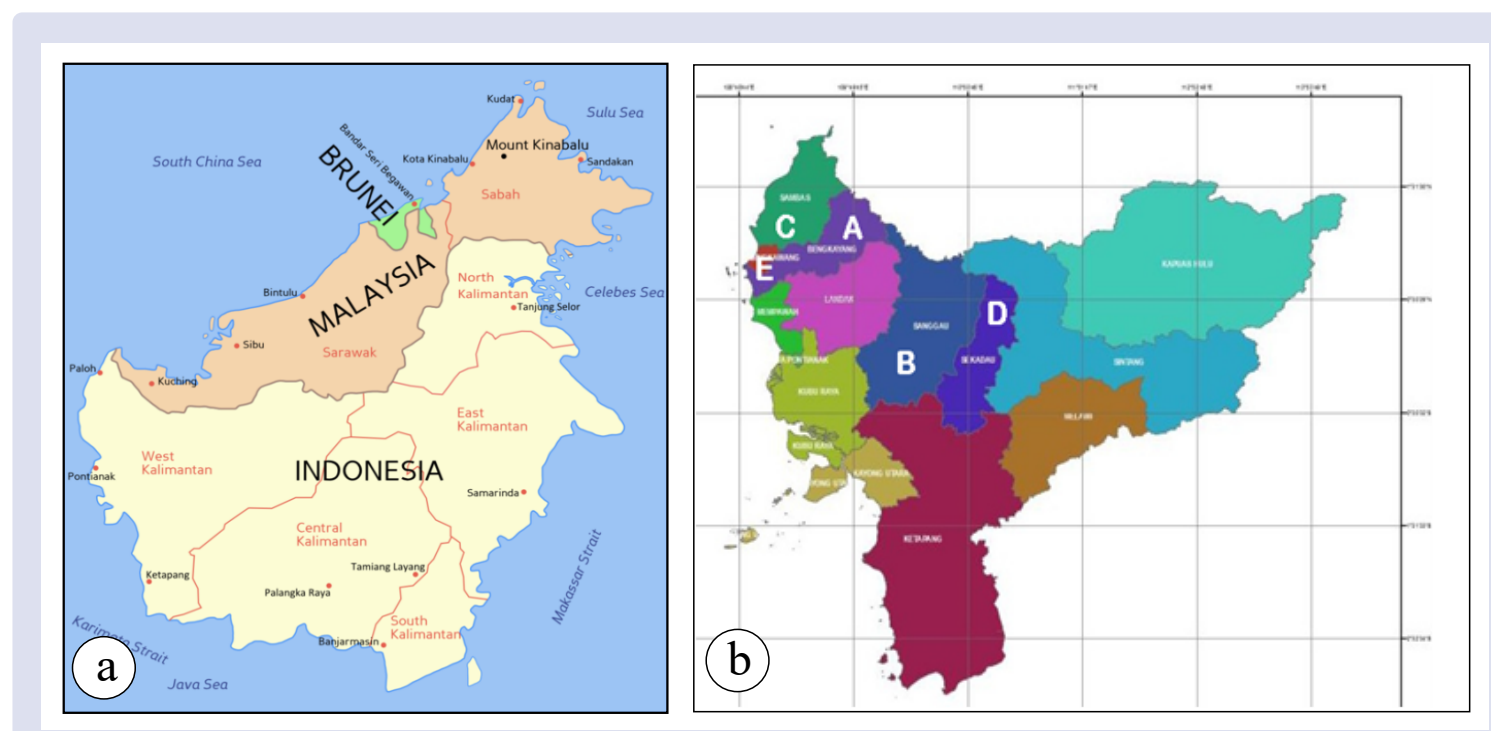

Figure 1: Map of research locations a. Map of Kalimantan Island and b. West Kalimantan Map: (A) Bengkayang Regency, (B) Sanggau Regency, (C) Sam bas Regency, (D) Sekadau Regency, and (E) Singkawang City). (Source: https://ppid.kalbarprov.go.id). 

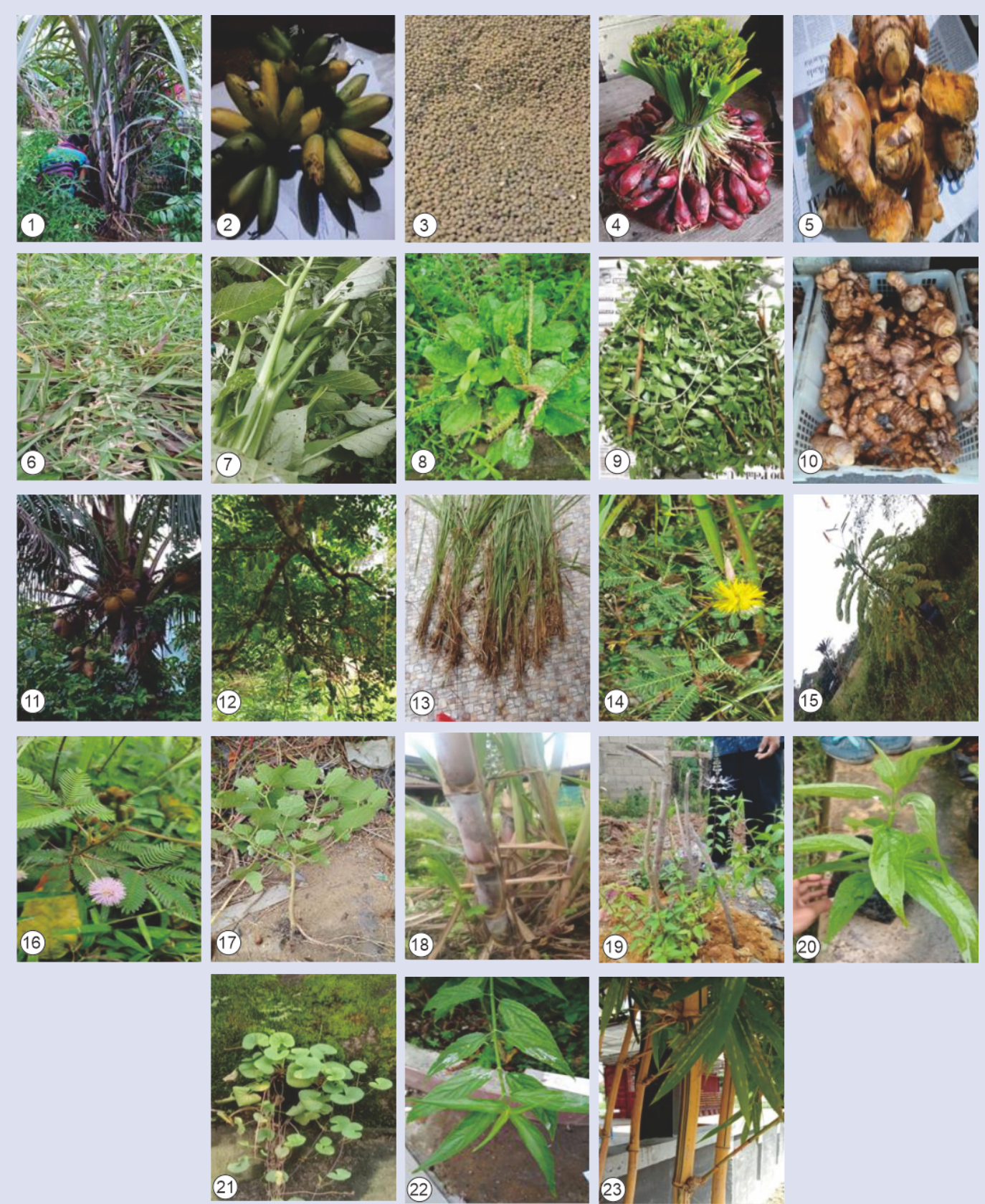

Figure 2: Various types of plants that can overcome jaundice used by ethnic Chinese, Dayaks, and Malays in West Kalimantan: 1.Tebu hitam (Saccharum officinarum L.), 2. Pisang mas (Musa paradisiaca L.), 3. Kacang hijau (Vigna radiata L.), 4. Bawang dayak (Eleutherine palmifolia (L.) Merr.), 5. Temulawak (Curcuma xanthorrhiza Roxb.), 6. Lipan-lipan (Chrysopogon aciculatus (Retz.) Trin), 7. Ciplukan (Physalis angulata L.), 8. Cha chen chou/ sawi (Plantago mayor L.), 9. Inai (Lawsonia inermis L), 10. Kunyit (Curcuma domestica Val.), 11. Kelapa gading (Cocos oburen Durch), 12. Belimbing manis (Averrhoa Carambola L.), 13. Ilalang (Imperata cylindrica (L) Beauv.), 14. Sia li chi o kin/putri malu kuning (Neptunia oleracea Lour.), 15. Ketepeng (Senna alata (L.) Roxb.), 16. Putri malu bunga ungu (Mimosa pudica L.), 17. Stet ma thio kin/bunga kancing (Urena lobata L.), 18. Tebu karak (Saccharum officinarum L.), 19. Kumis kucing (Orthosiphon aristatus (Blume) Miq.), 20. Empedu tanah/sambiloto (Andrographis paniculata (Burm.f.) Wall. ex Nees), 21. Pegage/pegagan (Centella asiatica L. Urban), 22. Kai kut chou/tulang ayam (Clinacanthus nutans (Burm.f.) Lindau), and 23. Bambu kuning (Bambusa vulgaris Schrad.). 
Table 1: Types of plants used to overcome jaundice by ethnic Chinese, Dayak, and Malay communities in West Kalimantan.

\begin{tabular}{|c|c|c|c|c|}
\hline No & Local Name & Scientific Name & Plant Organs Used & Regency/City \\
\hline 1. & Tebu hitam & Saccharum officinarum $\mathrm{L}$. & Stem & $\mathrm{C}$ \\
\hline 2. & Pisang mas & Musa paradisiaca $\mathrm{L}$. & Fruit & $\mathrm{E}$ \\
\hline 3. & Kacang hijau & Vigna radiata $\mathrm{L}$. & Seed & E \\
\hline 4. & Bawang dayak & Eleutherine palmifolia (L.) Merr. & Tuber & $\mathrm{A}, \mathrm{E}$ \\
\hline 5. & Temulawak & Curcuma xanthorrhiza Roxb. & Rhizome & $A, B, E$ \\
\hline 6. & Lipan-lipan & Chrysopogon aciculatus (Retz.) Trin & Stem and Leaf & A \\
\hline 7. & Ciplukan & Physalis angulata $\mathrm{L}$. & Root and Stem & $\mathrm{E}$ \\
\hline 8. & Cha chen chou (sawi) & Plantago major $\mathrm{L}$. & Root, Stem, and Leaf & $\mathrm{E}$ \\
\hline 9. & Inai & Lawsonia inermis $\mathrm{L}$ & Leaf & $\mathrm{C}$ \\
\hline 10. & Kunyit & Curcuma domestica Val. & Rhizome & $\mathrm{C}$ \\
\hline 11. & Kelapa gading & Cocos eburen Durch & a Flesh of Cocos & E \\
\hline 12. & Belimbing manis & Averrhoa carambola L. & Root & A \\
\hline 13. & Ilalang & Imperata cylindrica (L.) Beauv. & Root & E \\
\hline 14. & Sia li chi o kin (putri malu kuning) & Neptunia oleracea Lour. & Root & $\mathrm{E}$ \\
\hline 15. & Ketepeng & Senna alata (L.) Roxb. & Root & $\mathrm{D}$ \\
\hline 16. & Putri malu bunga ungu & Mimosa pudica $\mathrm{L}$. & Root & $\mathrm{B}, \mathrm{E}$ \\
\hline 17. & Stet ma thio kin (bunga kancing) & Urena lobata $\mathrm{L}$. & All parts of plant & $\mathrm{E}$ \\
\hline 18. & Tebu karak & Saccharum officinarum $\mathrm{L}$. & Stem & $\mathrm{E}$ \\
\hline 19. & Kumis kucing & Orthosiphon aristatus (Blume) Miq. & Root and Leaf & $\mathrm{E}$ \\
\hline 20. & Empedu tanah (sambiloto) & Andrographis paniculata (Burm.f.) Wall. Ex Nees & Root & $\mathrm{C}$ \\
\hline 21. & Pegage (pegagan) & Centella asiatica L. Urban & Leaf & $\mathrm{C}$ \\
\hline 22. & Kai kut chou (tulang ayam) & Clinacanthus nutans (Burm.f.) Lindau & Leaf and Stem & $\mathrm{C}$ \\
\hline 23. & Bambu kuning & Bambusa vulgaris Schrad. & Root & $\mathrm{A}, \mathrm{E}$ \\
\hline
\end{tabular}

Notes: (A) Bengkayang Regency, (B) Sanggau Regency, (C) Sambas Regency, (D) Sekadau Regency, and (E) Singkawang City

as alkaloids, steroids, terpenoids, amino acids, polyphenols, glycosides, and protein. ${ }^{33}$

Bawang dayak (Eleutherine palmifolia (L.) Merr) are reported to be effective in treating skin diseases caused by Staphylococcus aureus and Trichophyton rubrum ${ }^{35}$, inhibiting the growth of HeLa cells ${ }^{36}$, and anti-cholesterol. ${ }^{37}$ Besides, this plant is reported to contain phenolic compounds $^{38}$, flavonoids ${ }^{35,39}$, alkaloids, steroids, monoterpenoids, sesquiterpenoids, quinones, and tannins. ${ }^{35}$

Temulawak (Curcuma xanthorrhiza Roxb.) has reported various medicinal properties including anticancer, antioxidant, hepatoprotective, and nephroprotective $\mathrm{e}^{40}$, anti-hypercholesterolemic ${ }^{41}$, and a child's appetite enhancer. ${ }^{12}$ Temulawak rhizome is reported to contain flavonoid compounds ${ }^{12,42}$, saponins and tannins ${ }^{42}$, alkaloids, phenols, terpenoids, and glycosides. ${ }^{12}$

Ciplukan (Physalis angulata L.) has potential as anti-diarrhea ${ }^{43}$, antihypercholesterolemia ${ }^{44}$, anti-inflammatory ${ }^{45}$, immunomodulator ${ }^{46}$, antioxidants. ${ }^{46,47}$ The results of phytochemical tests showed that the ciplukan stem extract contains alkaloid, phenolic, flavonoid, terpenoid, and saponin compounds ${ }^{44}$, the fruit contains alkaloids, phenolics, flavonoids, and saponins ${ }^{44}$, while the ciplukan leaves contain a class of flavonoid compounds. ${ }^{47}$

Kunyit (Curcuma domestica Val.) is very familiar among people in Indonesia, especially this rhizome is often used as a spice in cooking and herbal/traditional ingredients. More than that, research results show that kunyit is useful as an appetite enhancer for children ${ }^{12}$, antioxidants and antimicrobial ${ }^{48}$, and anti-hepatitis C. ${ }^{49}$ The rhizome of Curcuma domestica Val. is reported to contain the alkaloid, flavonoid, phenol, terpenoid, and glycoside compound groups. ${ }^{12}$

Empedu tanah/sambiloto (Andrographis paniculata (Burm.f.) Wall. Ex Nees) has the potential as antidiabetic ${ }^{50}$, anti-cancer ${ }^{51}$, antibacterial $^{52}$, immunomodulators ${ }^{53}$, antioxidants and antimicrobial ${ }^{54}$, hepatoprotective ${ }^{55}$, and overcoming heart disease. ${ }^{56}$ Sambiloto leaves and roots are reported to contain classes of tannins, flavonoids, saponins, phenols, and glycosides. ${ }^{54}$
For the Chinese ethnic community in West Kalimantan, traditionally, kai kut chou or tulang ayam (Clinacanthus nutans (Burm.f.) Lindau) has manybenefits, including to treat bruises, lumbago, jaundice, antidiabetic, and kidney failure. From various studies, it is reported that this plant has potential as antimicrobial, antipoliferative, cytotoxic, antitumorigenic, anti-inflammatory, antimicrobial, and immunomodulator. ${ }^{57}$ Previously, Alam et al. ${ }^{58}$ reported that the Clicanthus nutans (Burm.f.) Lindau contains flavonoids, glycosides, glycoglycerolipids, cerebrosides, and monoacylmonogalatosylglycerol compounds.

Bambu kuning (Bambusa vulgaris Schrad.) or by the Dayak community in Bengkayang Regency, West Kalimantan, Indonesia is known as buluh bala. Fitri et al..$^{59}$ stated that the bambu kuning extract contains compounds that have the potential as an analgesic, antipyretic, antidiabetic, anti-inflammatory, antimicrobial, antioxidant, antiviral, hepatoprotective, and diuretic. Previously it was also proven that bambu kuning shoots have hepatoprotector activity and contain flavonoids and tannins. ${ }^{60}$

Pegagan (Centella asiatica L. Urban) or by the Malay community in West Kalimantan is called pegage. The results of the study prove that this plant has the potential to be cytotoxic against MCF-7 cells ${ }^{61}$, antitumor $^{62}$, antimalarial, ${ }^{63}$ and antidiabetic ${ }^{64}$. The methanol extract of this plant is reported contains alkaloids ${ }^{65}$, flavonoids and saponins $s^{65,66}$, steroids, tannins, and terpenoids ${ }^{66}$, also glycosides and phenols ${ }^{65}$.

Several previous studies have reported that scientifically Averrhoa carambola $\mathrm{L}$. has potential in medicine, including anti-inflammatory and anti-tumor properties ${ }^{67}$, antioxidants ${ }^{68}$, antimicrobial ${ }^{67}$. The root of this plant is also proven to have antidiabetic activity. ${ }^{69}$ Not only that, but the fruit of this plant also contains substances that act as anti-hypercholesterolemia and antioxidants. ${ }^{70}$ The ethanol extract of belimbing manis fruit is reported to contain flavonoids, phenols, saponins, terpenoids, and cardia glycosides. ${ }^{71}$ Belimbing manis fruit is also reported to contain nutrients such as potassium, calcium, magnesium, iron, phosphorus, carotene, vitamin B1, vitamin $\mathrm{B} 2$, and vitamin $\mathrm{C}$, as well as oxalic acid. ${ }^{72}$ 
Ketepeng leaves (Senna alata (L.) Roxb.) are reported to have antimicrobial properties ${ }^{73}$ and antidiabetic ${ }^{74}$. Besides, the leaves and roots of Senna alata L. are also proven to be antioxidants. ${ }^{75}$ Ketepeng leaf extract is reported to contain tannin, anthraquinone, and saponin compounds $^{73,75,76}$, alkaloids, glycosides, steroids, and terpenoids ${ }^{75}$, phenols ${ }^{73,75}$, flavonoids ${ }^{75,76}$.

Ilalang (Imperata cylindrica (L.) Beauv.) has potential as an anticancer. ${ }^{77}$ Not only that, but ilalang can also treat fever and jaundice ${ }^{78}$, antihypertensives ${ }^{79}$, and anti-inflammatory ${ }^{41}$.

Plantago major L. or by the Chinese in West Kalimantan is known as cha chen chou or sawi. From various studies, it is reported that this plant has various activities including antimicrobial, hepatoprotective, antidibetic, anti-cancer, anti-diarrhea, immunomodulatory, antioxidant ${ }^{80}$, and antimicrobial ${ }^{80,81}$. Phytochemical test results of Plantago major L. leaf extract showed the presence of carbohydrates, flavonoids, tannins, and alkaloids ${ }^{82}$.

Mimosa pudica L. is reported to have acted as antidiabetic and antihyperlipidemia ${ }^{83}$, as well as anti-hepatitis $\mathrm{B}^{84}$. Besides, this plant is also reported to have various potentials, including antimicrobial, anti-inflammatory, hepatoprotective, and antioxidant ${ }^{85}$. Mohan et al. $(2015)^{86}$ stated that the ethanol extract of Mimosa pudica L. leaves contains compounds of the terpenoids, flavonoids, glycosides, alkaloids, phenols, tannins, quinines, saponins, and coumarins. The ethanol extract of Mimosa pudica L. root is reported to contain flavonoids, tannins, and steroids. ${ }^{87}$

The results of previous studies showed that the leaves of Orthosiphon aristatus (Blume) Miq. has antimicrobial activity ${ }^{88}$, anti-cancer ${ }^{89}$, antioxidants ${ }^{6,89}$, and hepatoprotective ${ }^{90}$. Elya et al. $(2015)^{91}$ stated that the leaf extract contains the alkaloid, flavonoid, glycoside, steroid, terpenoid, and saponin compound.

The ethnic Chinese community in Singkawang Regency, West Kalimantan, Indonesia calls it sia li chi o kin or putri malu bunga kuning (Neptunia oleracea Lour. is synonymous with Neptunia prostrata (Lamk) Baillon). The results of previous research indicated that this plant has antioxidant and antimicrobial properties. ${ }^{92}$ This plant has also been shown to have antibacterial activity ${ }^{93}$ and antioxidants ${ }^{93,94}$. The various solvents used in the extraction process show that this plant extract contains a class of steroid and terpenoid compounds. ${ }^{95}$

\section{CONCLUSION}

There are 23 types of plants that can overcome jaundice which are used by ethnic Chinese, Dayak, and Malay people in West Kalimantan, namely tebu hitam (Saccharum officinarum L.), pisang mas (Musa paradisiacal L.), kacang hijau (Vigna radiata L.), bawang dayak (Eleutherine palmifolia (L.) Merr.), temulawak (Curcuma xanthorrhiza Roxb.), lipan-lipan (Chrysopogon aciculatus (Retz.) Trin), ciplukan (Physalis angulata L.), cha chen chou/sawi (Plantago mayor L.), inai (Lawsonia inermis L), kunyit (Curcuma domestica Val.), kelapa gading (Cocos eburen Durch), belimbing manis (Averrhoa carambola L.), ilalang (Imperata cylindrica (L) Beauv.), sia li chi o kin/putri malu kuning (Neptunia oleracea Lour.), ketepeng (Senna alata L.), putri malu bunga ungu (Mimosa pudica L.), stet ma thio kin/bunga kancing (Urena lobata L.), tebu karak, kumis kucing (Orthosiphon aristatus (Blume) Miq.), empedu tanah/sambiloto (Andrographis paniculata (Burm.f.) Wall. ex Nees), pegage/pegagan (Centella asiatica L. Urban), kai kut chou/tulang ayam (Clinacanthus nutans (Burm.f.) Lindau), and bambu kuning (Bambusa vulgaris Schrad.)

\section{ACKNOWLEDGMENT}

This research was carried out with funding from the Ministry of Research and Technology/National Research and Innovation Agency of the Republic of Indonesia, therefore we would like to thank you very much. Thanks are also conveyed to all informants who have shared their knowledge and knowledge about plants that can overcome jaundice. Thanks also to the regional heads who have helped to connect researchers with informants.

\section{CONFLICTS OF INTEREST}

Researchers state that this research is free from conflict of interest.

\section{REFERENCES}

1. Panjaitan RGP, Handharyani E, Chairul, Manalu W. Hepatoprotective activity of Eurycoma longifolia Jack. roots. Indian J Tradit Knowl. 2013;12(2):225-230

2. Mishra S, Aeri $V$, Katare DP. Hepatoprotective medication for liver Injury. World J Pharm Pharm Sci. 2014;3(5): 891-932.

3. Panjaitan RGP, Savitri E, Titin T. Hepatoprotective acivity of the ethanolic extract of dog fruit rind (Pithecellobium lobatum Benth.). J Kedok Hewan. 2017;11(3):109-112.

4. Shirani M, Raeisi R, Heidari-Soureshjani S, Asadi-Samani M, Luther T. A review for discovering hepatoprotective herbal drugs with least side effects on kidney. J Nephropharmacol. 2017;6(2):38-48.

5. Vasanthkumar T, Hanumanthappa M, Hanumanthappa SK. Hepatoprotective effect of curcumin and capsaicin against lipopolysaccharide induced liver damage in mice. Pharmacogn $\mathrm{J}$. 2017;9(6):947-951.

6. Chua LS, Lau CH, Chew CY, Ismail NIM, Soontorngun N Phytochemical profile of Orthosiphon aristatus extracts after storage: rosmarinic acid and other caffeic acid derivatives. Phytomedicine. 2018;39:49-55

7. Okaiyeto K, Nwodo UU, Mabinya LV, Okoh Al. A review on some medicial plants with hepatoprotective effects. Pharmacogn Rev. 2018;12(24):186-199.

8. Fargo MV, Grogan GSP, Saguil A. Evaluation of jaundice in adults. Am Fam Physician. 2017;95(3):165-168.

9. Abbas MW, Shamshad T, Ashraf MA, Javaid R. Jaundice : a basic review. Int J Res Med Sci. 2016;4(5):1313-1319.

10. Ali SA, Sharief NH, Mohamed YS. Hepatoprotective activity of some medicinal plants in Sudan. Evid-Based Complement Alternat Med. 2019;1-16.

11. Liem S, Levita J. Review hepatoprotektor rosela (Hibiscus sabdariffa): aktivitas, mekanisme aksi dan toksisitas. Galenika J Pharm. 2017;3(2):103-117.

12. Panjaitan RGP, Mitalia, Partasasmita R. Indigenous knowledge of the people in Karya Úsaha Hamlet (Kubu Raya, West Kalimantan, Indonesia) on the processing and diversity of plants that enhance toddler's appetite. Biodiversitas. 2020;21(9):4284-4290.

13. Fitmawati, Sofiyanti N, Roza RM, Isnani, Hazimi H, Irawan YR, et al. Traditional medicinal formulation: obat pahit from Lingga Malay ethnic in Riau Archipelago, Indonesia. Biodiversitas. 2017;18(3):1196-1200.

14. Nugrahani SS. Analisis perbandingan efektifitas ekstrak akar, batang, dan daun herba meniran dalam menurunkan kadar glukosa darah mencit. Unnes J Public Health. 2013;2(1):1-9.

15. Alsarhan A, Sultana N, Al-Khatib A, Kadir MRA. Review on some Malaysian traditional medicinal plants with therapeutic properties. J Basic Appl Sci. 2014;10:149-159.

16. Mainasara MM, Bakar MFA, Linatoc AC. Malaysian medicina plants' potential for breast cancer therapy. Asian J Pharm Clin Res. 2018;11(6):101-117

17. Zaki PH, Gandaseca S, Rashidi NM, Ismail MH. Traditional usage of medicinal plants by Temiar Tribes in the State of Kelantan, Peninsular Malaysia. For Society. 2019;3(2):227-234.

18. Flores RL, Legario RA, Malagotnot DBM, Peregrin K, Sato RA, Secoya ER. Ethnomedicinal study of plants sold in Quiapo, Manila, Philippines. Sch Acad J Biosci. 2016;4(4A):359-365.

19. Tantengco OAG, Condes MLC, Estadilla HHT, Ragragio EM. Ethnobotanical survey of medicinal plants used by Ayta Communities in Dinalupihan, Bataan, Philippines. Pharmacogn J. 2018;10(5):859870.

20. Li X, Chen Y, Lai Y, Yang Q, Hu H, Wang Y. Sustainable utilization of traditional Chinese medicine resources: systematic evaluation on different production modes. Evid-Based Complement Alternat Med. 2015:1-10 
21. LeeYS, Cho IJ, Kim JW, Lee MK, Ku SK, Choi JS, et al. Hepatoprotective effects of blue honeysuckle on $\mathrm{CCl}$-induced acute liver damaged mice. Food Sci Nutr. 2018;7(1):322-338.

22. Deb D, Datta BK, Debbarma J, Deb S. Ethno-medicinal plants used for herbal medication of jaundice by the indigenous community of Tripura, India. Biodiversitas. 2016;17(1):256-269.

23. Bahmani M, Rafieian-Kopaei M, Hassanzadazar H, Saki K, Karamati SA, Delfan B. A Review on most important herbal and synthetic antihelmintic drugs. Asian Pac J Trop Med. 2014;7(Suppl 1):S29-S33.

24. Karimi A, Majlesi M, Rafieian-Kopaei M. Herbal versus synthetic drugs; beliefs and facts. J Nephropharmacol. 2015;4(1):27-30.

25. Albuquerque UP, Cruz da Cunha LVF, Lucena RFP, Alves RRN. 2014. Methods and Techniques in Ethnobiology and Ethnoecology. Brazil: Humana Press

26. Uchenna EF, Adaeze OA, Steve AC. Phytochemical and antimicrobial properties of the aqueous ethanolic extract of Saccharum officinarum (sugarcane) bark. J Agric Sci. 2015;7(10):291-297.

27. Alves VG, Souza AG, Chiavelli LUR, Ruiz ALTG, Carvalho JE, Pomini $\mathrm{AM}$, et al. Phenolic compounds and anticancer activity of commercial sugarcane cultivated in Brazil. An Acad Bras Ciênc. 2016;88(3):12011209.

28. Pathak V, Tiwari VK. Phytochemical screening of Saccharum officinarum (Linn.) stem. Int J Innov Sci Res Technol. 2017;2(8):291305.

29. Timsina B, Nadumane VK. Anti-cancer potential of banana flower extract: an in vitro study. Bangladesh J Pharmacol. 2014;9(4):628-635.

30. Putra DAC, Lutfiyati $H$, Pribadi P. Effectiveness of banana leaves extract (Musa paradisiaca L.) for wound healing. Pharmaciana. 2017;7(2):177.

31. Lakshmi V, Agarwal SK, Mahdi AA. An overview of Musa paradisiaca Linn.. Nat Prod Indian J. 2015;11(4):105-109.

32. Andayani R, Afriana. Uji aktivitas antifungal ekstrak kulit pisang barangan (Musa paradisiaca L) terhadap Candida albicans. Cakradonya Dent J. 2016;8(1):1-7.

33. Sivakumar T. Phytochemical screening and gas chromatography-mass spectroscopy analysis of bioactive compounds and biosynthesis of silver nanoparticles using sprout extracts of Vigna radiata L. and their antioxidant and antibacterial activity. Asian J Pharm Clin Res. 2019;12(2):1-5

34. Fakhrudin N, Kurniailla NA, Fatimah KN. Potensi antioksidan biji dan daun kacang hijau (Vigna radiata L.) dan studi korelasinya dengan kadar flavonoid total. J Penelit Pascapanen Pertanian. 2020;17(1):4858.

35. Puspadewi R, Adirestuti P, Menawati R. Khasiat umbi bawang dayak (Eleutherine palmifolia (L.) Merr.) sebagai herbal antimikroba kulit. Kartika J IImiah Farmasi. 2013;1(1):31-37.

36. Mutiah R, Listyana A, Suryadinata A. Aktivitas antikanker kombinasi ekstrak benalu belimbing (Macrosolen cochinensis) dan bawang sabrang (Eleutherine palmifolia (L) Merr.) pada sel kanker serviks (Sel HeLa). Tradit Med J. 2017;22(3):146-152.

37. Kusuma AM, AsarinaY, RahmawatiYI, Susanti S. Efek ekstrak bawang dayak (Eleutherine palmifolia (L.) Merr) dan ubi ungu (Ipomoea batatas $L$ ) terhadap penurunan kadar kolesterol dan trigliserida darah pada tikus jantan. J Kefarmasian Indones. 2016;6(2):108-116.

38. Sasongko A, Nugroho RW, Setiawan CE, Utami IW, Pusfitasari MD. Penentuan total fenol ekstrak umbi bawang dayak hasil ekstraksi dengan metode ultrasound assisted extraction (UAE) dan ultrasonicmicrowave assisted extraction (UMAE). J Sains Terapan. 2017;3(2):4247.

39. Kumalasari E, Nazir MA, Putra AMP. Penetapan kadar flavonoid total ekstrak etanol $70 \%$ daun bawang dayak (Eleutherine palmifolia L.) dengan metode spektrofotometri UV-Vis. J Insan Farm Indones.2018;1(2):201-209.

40. Oon SF, Nallappan M, Tee TT, Shohaimi S, Kassim NK, Sa'aruwujaya MSF, et al. Xanthorrhizol: a review of its pharmacological activities and anticancer properties. Cancer Cell Int. 2015;15(100):1-15.
41. Aznam N, Atun S. The development of temulawak (Curcuma xanthorrhiza) herb production and pharmacological test as antihypercholesterolemia. Int J Green Pharm. 2017;11(4):809-813.

42. Putri R, Mursiti S, Sumarni W. Aktivitas antibakteri kombinasi temu putih dan temulawak terhadap Streptococcus mutans. Indones J Math Nat Sci. 2017;40(1):43-47.

43. Fajaryanti, N. dan Kurniawati NI. Efek antidiare infusa daun ciplukan (Physalis angulata Linn) pada mencit jantan putih (Mus musculus) yang terpapar oleum ricini. J Farmasetis. 2018;7(1):19-22.

44. Afriyeni H, Surya S. Efektivitas antihiperkolesterolemia ekstrak etanol dari bagian batang dan buah tumbuhan ciplukan (Physalis angulata L.) pada tikus putih hiperkolesterolemia. J Farm Higea. 2019;11(1):49-61.

45. Rivera D, Ocampo Y, Franco LA. Physalis angulata calyces modulate macrophage polarization and alleviate chemically induced intestinal inflammation in mice. Biomedicines. 2020;8(2): 1-11.

46. Kusumaningtyas RW, Laily N, Limandha P. Potential of ciplukan (Physalis angulata L.) as Source of functional ingredient. Procedia Chem. 2015;14:367-372.

47. Cobaleda-Velasco M, Alanis-Bañuelos RE, Almaraz-Abarca N, RojasLÓpez M, Gonzáles-Valdez LS, Ávila-Reyes JA, et al. Phenolic profiles and antioxidant properties of Physalis angulata L. as quality indicators. J Pharm Pharmacogn Res. 2017;5(2):114-128.

48. Septiana E, Simanjuntak P. Aktivitas antimikroba dan antioksidan ekstrak beberapa bagian tanaman kunyit (Curcuma longa). Fitofarmaka. 2015;5(1):146-156

49. Wahyuni TS, Permatasari AA, Widiandani T, Fuad A, Widyawaruyanti A, Aoki-Utsubo C, et al. Antiviral activities of Curcuma genus against hepatitis C virus. Nat Prod Commun. 2018;13(12):1579-1582.

50. Thakur AK, Rai G, Chatterjee SS, Kumar V. Beneficial effects of an Andrographis paniculata extract and andrographolide on cognitive functions in streptozotocin-induced diabetic rats. Pharm Biol. 2016;54(9):1528-1538.

51. Rajeshkumar S, Nagalingam M, Ponnanikajamideen M, Vanaja $M$, Malarkodi C. Anticancer activity of Andrographis paniculata leaves extract against neuroblastima (IMR-32) and human colon (HT-29) Cancer Cell Line. World J Pharm Pharm Sci. 2015;4(6):1667-1675.

52. Mishra PK, Singh RK, Gupta A, Chaturvedi A, Pandey R, Tiwari SP, et al. Antibacterial activity of Andrographis paniculata (Burm. f.) Wall ex Nees leaves against clinical pathogens. J Pharm Res. 2013;7(5):459462.

53. Rahayu MP. Aktivitas imunomodulator fraksi $n$-heksan dari herba sambiloto (Andrographis paniculata (Burm. F) Nees) terhadap mencit yang diinduksi vaksin hepatitis B dengan parameter Ig G. J Pharmascience. 2015;2(1):35-43.

54. Polash SA, Saha T, Hossain MS, Sarker SR. Investigation of the phytochemicals, antioxidant, and antimicrobial activity of the Andrographis paniculata leaf and stem extracts. Adv Bioscie Biotechnol. 2017;8:149-162.

55. Puri SK, Habbu PV, Kulkarni PV, Kulkarni VH. Evaluation of endophytic fungal fractions of Andrographis paniculata (Burn.f.) Wall. Nees leaves for in vitro free radical scavenging and hepatoprotective activity. Int J Res Pharm Sci. 2018;9(1):1-17.

56. Wu QQ, Ni J, Zhang N, Liao HH, Tang QZ, Deng W. Andrographolide protects against aortic banding-induced experimental cardiac hypertrophy by inhibiting MAPKs signaling. Front Pharmacol. 2017;8:1-17.

57. Zulkipli IN, Rajabalaya R, Idris A, Sulaiman NA, David SR. Clinacanthus nutans: a review on ethnomedicinal uses, chemical constituents and pharmacological properties. Pharm Biol. 2017;55(1):1093-1113.

58. Alam A, Ferdosh S, Ghafoor K, Hakim A, Juraimi AS, Khatib A, et al. Clinacanthus nutans: a review of the medicinal uses, pharmacology and phytochemistry. Asian Pacific J Trop Med. 2016;9(4):402-409.

59. Fitri A, Asra R, Rivai H. Overview of the traditional, phytochemical, and pharmacological uses of gold bamboo (Bambusa vulgaris). World J Pharm Pharm Sci. 2020;9(8):299-318. 
60. Nuari DA, Qowwiyah A, Eksyawati D. Hepatoprotective activity of yellow bamboo (Bambusa vulgaris Schard) white rats. J IImu Farmako Bahari. 2018;9(2):16-22.

61. Paudel P, Satyal P, Dosoky NS, Setzer WN. Chemical composition and biological activity of Centella asiatica essential oil from Nepal. Am J Essent Oils Nat Prod. 2017;5(4):5-8

62. Hamid IS, Widjaja NMR, Damayanti R. Anticancer activity of Centella asiatica leaves extract in Benzo(a)pyrene-induced mice. Int $\mathrm{J}$ Pharmacogn Phytochem Res. 2016;8(1):80-84.

63. Banyal HS, Devi V, Devi N. Bioefficacy of Centella asiatica (Linnaeus) Urban on Plasmodium berghei Vincke and Lips, 1948. Asian J Biol Sci. 2014;7(5):238-241.

64. Fitrianda E, Sukandar EY, Elfahmi, Adnyana IK. Antidiabetic activity of extract, fractions, and asiaticoside compound isolated from Centella asiatica Linn. leaves in alloxan-induced diabetic mice. Asian J Pharm Clin Res. 2017;10(10):268-272

65. Saranya S, Nair AV, Prathapan P, Neethu AS, Kumar NS. Phytochemical analysis of Centella asiatica L. leaf extracts. Int J Adv Res. 2017;5(6):1828-1832.

66. Roy A, Krishnan ML, Bharadvaja N. Qualitative and quantitative phytochemical analysis of Centella asiatica. Nat Prod Chem Res. 2018;6(4):1-4.

67. Saghir SAM, Sadikun A, Khaw KY, Murugaiyah V. Star fruit (Averrhoa carambola L.): from traditional uses to pharmacological activities. Bol Latinoam Caribe. 2013;12(3):209-219.

68. Silva KB, Pinheiro CTS, Soares CRM, Souza MA, Matos-Rocha TJ, Fonseca SA, etal. Phytochemical characterization, antioxidant potential and antimicrobial activity of Averrhoa carambola L. (Oxalidaceae) against multiresistant pathogens. Braz J Biol. 2020;1(1):1-7

69. Xu X, Liang T, Wen Q, Lin X, Tang J, Zuo Q, et al. Protective effects of total extracts of Averrhoa carambola L. (Oxalidaceae) roots on streptozotocin-induced diabetic mice. Cell Physiol Biochem. 2014;33(5):1272-1282.

70. Harinisri K, Madhanasundareswari K, Arthikha R. Antimicrobial and phytochemical analysis of Averrhoa carambola and its study on cholesterol-lowering effects. Int J Sci Technol Res. 2019;8(10):738742

71. Khanam Z, Sam KH, Zakaria NHBM, Ching CH, Bhat IUH. Determination of polyphenolic content, HPLC analyses and DNA cleavage activity of Malaysian Averrhoa carambola L. fruit extracts. J King Saud Univ Sci. 2015;27(4):331-337.

72. Muthu N, Lee SY, Phua KK, Bhore SJ. Nutritional, medicinal and toxicological attributes of star-fruits (Averrhoa carambola L.): a review. Bioinformation. 2016;12(12):420-424

73. Jayachitra J, Pavithra K,Pandian RS, Bharathi V, Shanthi S. Phytochemical and antimicrobial analysis of Senna alata leaves extract. World J Pharm Res. 2018;7(14):1030-1044.

74. Kazeem MI, Azeez GA, Ashafa AOT. Effect of Senna alata (L) Roxb (Fabaceae) Leaf extracts on alpha-amylase, alpha-glucosidase and postprandial hyperglycemia in rats. Trop $\mathrm{J}$ Pharm Res. 2015:14(10):1843-1848.

75. Abubakar I, Mann A, Mathew JT. Phytochemical composition, antioxidant and anti-nutritional properties of root-bark and leaf methanol extracts of Senna alata L. grown in Nigeria. Afr J Pure Appl Chem. 2015;9(5):91-97.

76. Oladeji SO, Adelowo FE, Odelade KA. Mass spectroscopic and phytochemical screening of phenolic compounds in the leaf extract of Senna alata (L.) Roxb. (Fabales: Fabaceae). Braz J Biol Sci. 2016;3(5):209-219.

77. Keshava R, Muniyappa N, Gope R, Ramaswamaiah AS. Anti-cancer effects of Imperata cylindrica leaf extract on human oral squamous carcinoma cell line SCC-9 in vitro. Asian Pac J Cancer Prev. 2016;17(4):1891-1898.
78. Abdullah FO, Hussain FHS, Sardar AS, Vita-Finzi P, Vidari G. Phytochemistry and ethnopharmacology of medicinal plants used on Safeen Mountain in the Kurdistan Region of Iraq. Nat Prod Commun. 2016;11(12):1923-1927.

79. Ruslin, Asmawi MZ, Rianse U, Sahidin, Dhianawaty D, Soemardji AA, et al. Anti-hypertensive activity of alang-alang (Imperata cylindrica (L.) Beauv. root methanolic extract on male Wistar rat. Int J Res Pharm Sci. 2013;4(4):537-542.

80. Vandana J, Gupta AK, Mukerjee A. Pharmacological activities of miraculous plant Plantago major L.: A review. Int J Chem Phys Sci. 2017;6(3):26-37.

81. Fayera S, Babu G N, Dekebo A, Bogale Y. Phytochemical investigation and antimicrobial study of leaf extract of Plantago lanceolata. Nat Prod Chem Res. 2018;6(2):1-8.

82. Lukova P, Dimitrova-Dyulgerova I, Karcheva-Bahchevanska D, Mladenov R, lliev I, Nikolova M. Comparative morphological and qualitative phytochemical analysis of Plantago media $\mathrm{L}$. leaves with P. major L. and P. lanceolata L. leaves. Int J Med Res Pharm Sci. 2017;4(6):20-26.

83. Parasuraman $\mathrm{S}$, Ching $\mathrm{TH}$, Leong $\mathrm{CH}$, Banik U. Antidiabetic and antihyperlipidemic effects of a methanolic extract of Mimosa pudica (Fabaceae) in diabetic rats. Egyptian J Basic Appl Sci. 2019;6(1):137148.

84. Rohan N, Durgadevi P, Mythily VB, Elanchezhiyan M. Prevention of hepatitis $B$ virus (HBV) replication by extracts of Mimosa pudica, an unique Indian medicinal plant. Bioinfo Drug Targets. 2014;2(1):20-23.

85. Muhammad G, Hussain MA, Jantan I, Bukhari SNA. Mimosa pudica L., a high-value medicinal plant as a source of bioactives for pharmaceuticals. Compr Rev Food Sci Food Saf. 2016;15(2):303-315.

86. Mohan SM, Pandey B, Rao SG. Phytochemical analysis and uses of Mimosa pudica Linn. in Chhattisgarh. Journal of Environmental Science, Toxicol Food Technol. 2015;1(3):1-4.

87. Shashikumara, Prathima C, Amrutheswari B. Effect of ethanolic extract of Mimosa pudica $\mathrm{L}$. root on acute restraint stress-induced anxiety and depression in swiss albino mice. Asian J Pharm Clin Res. 2018;11(10):182-186

88. Mangali GR. Antimicrobial activity of Orthosiphon aristatus (balbas pusa) nano particle and leaf extract against E. coli and S. aureus. World J Pharm Pharm Sci. 2020;9(3):174-199.

89. Rajani P, Kotaiahm M R, Sekar KB C. Evaluation of antioxidant and anticancer activities of Orthosiphon aristatus. Int J Res Pharm Sci. 2015;6(2):193-198

90. Reshi NA, Shankarsingh SM, Hodiyala GV. Hepatoprotective activity of leaf and leaf callus extracts of Orthosiphon aristatus (Blume) Miq Br J Pharm Res. 2017;15(3):1-8.

91. Elya B, Handayani R, Sauriasari R, Azizahwati, Hasyyati US, Permana IT, et al. Antidiabetic activity and phytochemical screening of extracts from Indonesian plants by inhibition of alpha amylase, alpha glucosidase and dipeptidyl peptidase IV. Pak J Biol Sci. 2015;18(6):279284.

92. Chakraverty R, Aon P, Debnath T, Deb PK, Chakraborty P. Elucidation of the antioxidant and antimicrobial activity of extracts of leaves of Neptunia prostrata Linn. Int J Pharm Phytopharmacol Res. 2019;9(6):76-80.

93. Sagolshemcha R, Singh R W. Traditional and biological uses of Neptunia oleracea Lour: An overview. Int J Curr Res. 2017;9(6):5168951694.

94. Lee SY, Mediani A, Ismail IS, Maulidiani, Abas F. Antioxidants and $\alpha$-glucosidase inhibitors from Neptunia oleracea fractions using ${ }^{1} \mathrm{H}$ NMR-based metabolomics approach and UHPLC-MS/MS analysis. BMC Complement Altern Med. 2019;19(7):1-15.

95. Deb PK, Das S, Bhaumik KN, Ghosh R, Ghosh TK, Bhakta T. Pharmacognotic and preliminary phytochemical investigation of Neptunia prostrata L. J Pharmacogn Phytochem. 2013;2(3):5-11. 


\section{GRAPHICAL ABSTRACT}

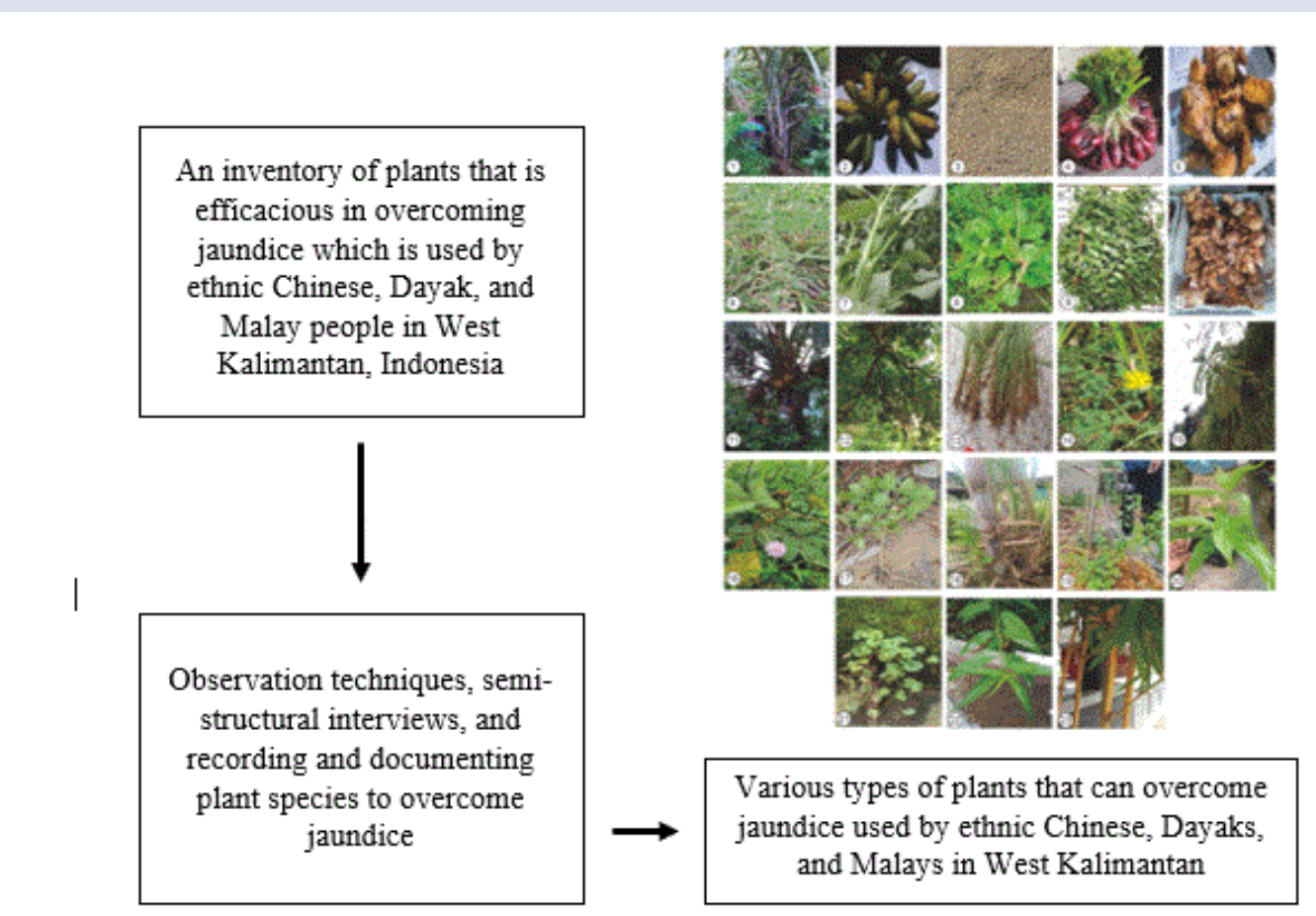

\section{ABOUT AUTHORS}

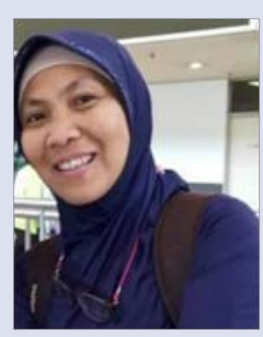

Ruqiah Ganda Putri Panjaitan, graduated from the Department of Biology, FMIPA Andalas University, Padang. She got her masters and doctorates from the Department of Biology FMIPA Bogor Agricultural University. Her field of interest is the study of medicinal plant activity. Now, she is working as a lecturer in Tanjungpura University.

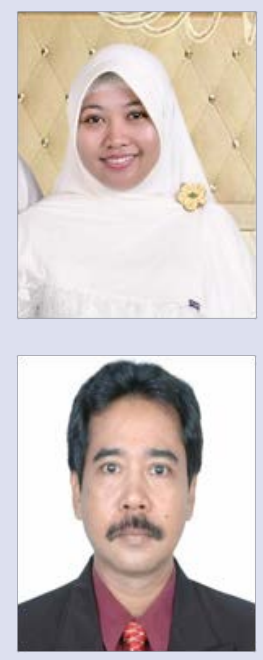

Titin, S.Pd. Si, M.Pd, graduated from Department of Biology Education, Yogyakarta State University in 2006. She got her master from the Department of Science Education, Sebelas Maret University in 2012. Now, she is working as a Biology Education Lecturer in Tanjungpura University. Her field of expertise is a Science Education. She teaches Teaching and Learning, Plant Morphology, and Plant Taxonomy.

Yohanes Gatot Sutapa Yuliana is a lecturer of Undergraduate and Master Study Program of English Language Education of Tanjungpura University. He wrote his doctoral dissertation on English teaching material development for vocational schools. He also attended sandwich-like for visiting scholar program in University of Illinois at Urbana USA 2010, and Community Development Program in Kansas State Univeristy 2019. On his professional duties, he teaches Research Approaches, TEFL Assessment, TEFL Methodologies, Academic Writing and Presentation, and Research Paper, besides doing research on localized folklore.

Cite this article: Panjaitan RGP, Titin, Yuliana YGS. Ethno-Medicinal Plants Used for Medication of Jaundice by The Chinese, Dayak, and Malays Ethnic in West Kalimantan, Indonesia. Pharmacog J. 2021;13(4): 916-923. 